Institute of

Public Finance
NEWSLETTER

AN OGGASIONAL PUBLIGATION OF THE INSTITUTE OF PUBLIG FINANGE

\title{
Changes in the Value Added Tax System
}

\author{
DANIJELA KULIŠ Institute of Public Finance
}

\begin{abstract}
At its session held on 17 February 2012, the Croatian Parliament passed the Act on Amendments to the Value Added Tax (VAT) Act. Even without being labelled as "a mater of urgency", the underlying legislative procedure (starting with the announcement of the Amendments late in 2OII, and ending with the completion of the Government and parliamentary procedures and entry into force of the Act on I March) was quick enough to be considered as urgent. The tax reform package also included amendments to the personal income tax and corporate income tax acts, as well as to the mandatory contributions act. The consequences of the tax legislation changes will be borne by all of us - from the public and economy sectors to citizens. Given the substantiality of the changes adopted at such short notice and amidst the crisis, it is worth examining whether all effects of the changes have been properly analysed and considered. The adoption of the 2012 State Budget, budget revenue shortfall and the increase in expenditure over the period 2008-10, fiscal imbalance, as well as the deficit and public debt growth - are reasons enough to introduce the necessary fiscal measures aimed at consolidating the overall government finance. This article deals with changes envisaged in the area of value added taxation.
\end{abstract}

\section{GHANGES IN THE VAT SYSTEM}

An increase in the general VAT rate is hardly a popular measure, but if it is accompanied by changes in income taxation (raising the personal allowance), cuts in health insurance contribution rate and extension of the scope of products taxed at reduced VAT rates, the burden of VAT can be relieved to some extent.

An analysis of the aforementioned changes is given below.

\begin{abstract}
The amendments to the VAT Act include the following:

- Increase in the general rate from $23 \%$ to $25 \%$;

- Introduction of a reduced Io\% rate on edible oils and fats of plant and animal origin, infant food and processed food based on cereals for babies and infants, the supply of water, except water delivered in bottles or other containers and white cane or beet sugar;

- Abolition of input VAT deduction for the procurement and maintenance of vessels, planes, personal motor vehicles and other personal means of transportation;

- Abolition of input VAT deduction for the procurement of goods and services for entertainment purposes;

- Increase in the VAT registration threshold; and

- Changes in penal provisions.
\end{abstract}

\section{GHANGES IN VAT RATES}

During the general economic and fiscal crisis, gripping not only the EU member states, "tax interventions" usually include tax rate increases, aimed at filling the budget and reducing deficit. Among the EU member states, Hungary currently holds a leading position in this respect ${ }^{\mathrm{I}}$, having raised its VAT rate from $25 \%$ to $27 \%$. Cyprus, Czech Republic, Ireland and United Kingdom intend to raise their rates in 2012, whereas Bulgaria, France, Italy, Lithuania and Poland envisage doing so during the current year or over the next few years. This can be considered as a typical tax policy instrument aimed at increasing the tax revenue. Even the European Commission, on the occasion of proposing the 20I4-2O EU budget, suggested the introduction of a VAT at a rate of $\mathrm{I} \%$ across the EU, which would be collected directly from taxpayers in the Member States, 
instead of as shares in national VAT revenues ${ }^{2}$. The future of this proposal is questionable and highly uncertain, and it should remain subject to debate until end-2OI2.

As expected, the announced changes in the VAT system, especially the rate increase from $23 \%$ to $25 \%$, attracted most attention of both economic experts and the public. In order to, at least slightly, relieve the heavier tax burden, the list of products to be taxed at a reduced rate of IO\% has been extended.

\section{INCREASE IN THE GENERAL VAT RATE}

The tax system participants are two interested (but not necessarily opposed) parties: tax authorities on the one side and taxpayers, bearing the tax burden on the other. The tax authorities try to collect additional revenues from higher tax, whereas the taxpayers, meeting their legally prescribed tax liabilities, also bear the consequences of tax changes (such as price increases, reduced spending, etc.). In the case of consumption taxes (VAT and excise duties), participating with almost $60 \%$ in the national budget and applying to the bulk of taxpayers, even the smallest change has multiple effects.

Estimates are that an increase in the VAT rate by 2 percentage points would raise the revenues from the planned HRK 39.3bn in 2OII to HRK 4O.5bn in 2OI2, i.e. by HRK I.2bn or 3.I\%. ${ }^{3}$ The amount of the tax rate affects budget revenues, but also the quantities and prices of goods and services, and, indirectly, the income, consumption, competitiveness in the market and living standards of citizens.

\section{Table I.}

Tax revenues in the RC, 2008-I2

\begin{tabular}{|c|c|c|c|c|c|}
\hline & 2008 & 2009 & 2010 & $\begin{array}{c}2011 \\
\text { (plan) }\end{array}$ & $\begin{array}{c}2012 \\
\text { Budget }\end{array}$ \\
\hline $\begin{array}{l}\text { Total State } \\
\text { Budget revenue } \\
\text { (excluding } \\
\text { contributions, } \\
\text { in million HRK) }\end{array}$ & II 5,773 & IIO,258 & IO7,466 & I07,052 & 108,649 \\
\hline $\begin{array}{l}\text { VAT revenues } \\
\text { (in million HRK) }\end{array}$ & $4 \mathrm{I}, 3 \mathrm{O} 8$ & 37,050 & 37,689 & 39,3 I4 & 40,522 \\
\hline $\begin{array}{l}\text { Share of VAT } \\
\text { revenues in total } \\
\text { tax revenues (\%) }\end{array}$ & 35.8 & 33.0 & 35.7 & 36.2 & 37.0 \\
\hline
\end{tabular}

Sources: Ministry of Finance of the RC (2012) and Croatian Parliament (20I2).

2 The rate stands at $0.3 \%$ of the national VAT revenues and is applied to a base, which may not exceed 50\% of GDP. Also applied are temporary reduced rates for the period 2007-13 (0.225\% for Austria, 0.15\% for Germany and 0.1\% for the Netherlands and Sweden).

3 Probably based on the Guidelines for the Preparation of the 2012 Budget, the increase presented in the media amounts to HRK 2.5bn, as opposed to the Budget figure of HRK I.2bn.

\section{DOES A HIGHER TAX RATE MEAN MORE TAX REVENUES?}

Can an increase in the VAT rate in itself result in higher revenues? As of I August 2009, the VAT rate went up from $21 \%$ to $23 \%$, but revenues from this tax decreased from July. Only in the third quarter, the revenues rose by II.7\% from the second quarter (probably due to the seasonal effect), and in the fourth quarter, they fell by 1.5\% from the previous three-month period. Total VAT revenues in 2009 were almost 10\% lower than in 2008. According to the Ministry of Finance's Yearbook 2009, the revenue cut was due to an economic downturn in 2009, particularly a decline in personal consumption. Hence, the increase in the VAT rate did not automatically lead to higher revenues.

The Guidelines for the Preparation of 2012 Budget (Ministry of Finance of the RC, 2OI2) provide an estimate of the financial effects of changes in VAT rates. "An increase in the general value added tax rate by two percentage points will produce additional revenues for the national budget of about HRK 3 billion annually. A cut in the VAT rate from $23 \%$ to IO\% for edible oils and fats would reduce the revenues by about HRK 220 million annually, for infant food by about HRK 75m, and for the supply of water by HRK I6om. The aggregate annual effect of all the proposed changes in the VAT system would be an increase in budget revenues by about HRK 2.5bn". In the 2012 Budget Proposal, the increase in revenues due to the changes in VAT is estimated at HRK I.2 billion, which is HRK I.3 billion less than planned in the Guidelines.

All this shows how uncertain it is to plan revenues from the change in VAT rates, because, apart from the rates, they depend on a series of other factors.

\section{DOES A HIGHER RATE MEAN HIGHER PRIGES AND LOWER CONSUMPTION?}

It may be intuitively concluded that higher taxes lead to higher prices of goods and services on which the tax is charged, although one should not ignore the fact that prices are influenced by a lot of other factors (market relationships, competitiveness, etc.).

A simple calculation would be to increase the collected tax revenues, assuming all other factors remain unchanged, by the percentage growth of the rate (i.e. $8.7 \%$ ). However, business mathematics is not that simple. The Ministry of Finance has said rather optimistically that "there is not a single reason why an increase in the VAT rate could influence price growth, counting on fair play by both entrepreneurs and traders" (Vresnik, 20I2). It is hard to expect from producers and traders to take on the tax burden and refrain from shifting it to consumers. More realistic is the statement by B. Grčić, the Government's eco- 
nomic strategist, that "prices might see a very slight correction, by no more than I.4\%" (Vresnik, 2OI2).

The growth in prices is not necessarily the consequence of higher tax rates. Compared with 20I0, when there were no tax rate increases, consumer prices went up by $2.3 \%$ in $2 \mathrm{OII}$ (CBS, 2OI2). The sharpest increase (22.3\%) was seen in the prices of liquid fuels, alcoholic beverages and tobacco $(6.8 \%$, due to the effect of excise duties). Food products prices rose by $3.5 \%$, especially the prices of edible oils and fats ( $\mathrm{I} 6 . \mathrm{I} \%)$, followed by bread and cereals (5.4\%). Regardless of the cause, the growth in prices changes the behaviour of consumers, producers and traders. Consumers will no more be able or willing to buy certain products and consumption will shrink, which can result in lower tax revenues despite the higher rate. Reduction in consumption also depends on demand elasticity. If demand for a certain good is inelastic, a heavier tax burden will not change the amount of the sales (Urban, 2OII). Price elasticity is mainly low for basic foodstuffs and necessities of life (also for products subject to excise duties). It is therefore expected that the change in the prices of these goods will not significantly reduce their consumption. However, as prices grow, demand shrinks for products other than the necessities of life, e.g. some food products, clothing, footwear, non-alcoholic beverages, furniture, home equipment and apparatus, including transportation services, telecommunication, maintenance and repairs. Will citizens, due to higher tax and, consequently, higher prices, partly or fully give up consuming these products and services?

Provided that the laws of the market (i.e. of demand and supply) operate and that there is competition, it can be expected that, due to a possible decrease in sales, and the cross-border shopping in the neighbouring countries (with lower tax rates, e.g. 20\% in Slovenia or $17 \%$ in Bosnia and Herzegovina) some domestic producers and traders will reduce their trading margins in order to boost sales.

\section{IMPACT ON THE LIVING STANDARDS}

In contrast to the personal income tax which is progressive (persons with higher incomes pay higher tax amounts), VAT is regressive. The share of expenditures for the purchase of goods in income is much larger for lower-income citizens than it is for higher-income ones (Urban, 2OII). Therefore, it is feared that the higher VAT rate will be most detrimental to lowest-income groups. According to the estimate of the president of Independent Trade Unions of Croatia ${ }^{4}$, monthly expenses would go up by about Ioo kuna or I.46\%, but the effect of that increase should be alleviated to some extent by changes in the per-

4 “Jutarnji list”, I2 February 2012. sonal income tax for lowest-income groups, and by cutting the VAT rates on certain products.

Regressive effects of VAT should be offset by introducing a social transfer system or by the progressive effects of other taxes. Instead of lower VAT rates on infant food, edible oils and fat, sugar, water, etc., which should make up for the cost of living growth due to an increase in VAT from $23 \%$ to $25 \%$, it would be better to provide aid directly to the lowest-income citizens and increase the basic personal allowance for the purpose of personal income taxation (Ott, 2OI2).

\section{INTRODUGING A LOWER RATE FOR A NEW GROUP OF PRODUGTS}

An ideal VAT system would be the one with a single rate, a broad tax base and minimum exemptions (Kesner-Škreb, 1999). Despite the undeniable economic benefits of a single-rate VAT system, the most debate is usually focused on the number and levels of VAT rates. Among the EU member states, only Denmark applies a single rate $(25 \%)$, whereas others have two to even four rates (France, Ireland and Luxembourg). Like most countries, Croatia currently applies three rates (two rates and a zero-rate). Since the zero-rate is about to be abolished as Croatia joins the $\mathrm{EU}$, there will be two rates (a general and a reduced rate). The EU legislation allows a maximum of two reduced rates, so it is likely that Croatia, too, will be exposed to pressures for introducing another reduced rate.

According to the current amendments to the Act, some new products will be taxed at a reduced rate of IO\% instead of the former rate of $23 \%$. As of I January 2013, the IO\% rate will also be applied to tourism and catering services (food preparation and serving in catering establishments, and to the preparation and serving of non-alcoholic drinks and beverages, wine and beer in such establishments, pursuant to special regulations).

\section{ADVANTAGES AND DRAWBACKS OF LOWER-RATE TAXATION}

Tax exemptions and reduced and zero rates are introduced to cushion the regressive effect of VAT. However, the application of reduced rates raises a number of issues.

First, who benefits from reduced rates? Although intended primarily for poor citizens, they are beneficial for higherincome groups as well.

Second, what happens to prices? Will they go down due to a lower tax rate? There are two possible scenarios here (Ott et all., 1996).

According to the first one, after the change in the VAT rate, all producers and traders in the value added chain 
will accurately calculate VAT. This means that the products currently taxed at a rate of $23 \%$ will go up precisely by the difference between that rate and the new rate of $25 \%$. The prices of products currently taxed at a rate of $23 \%$ and from I March on at a rate of IO\% will be reduced by that difference.

The other scenario foresees that some producers and traders will take advantage of the change in tax rates and unjustifiably raise prices (if only minimally), or that they will not reduce prices by exactly the difference between the old and the new rate. A problem also occurs in the manufacturing chain of products taxed at a reduced rate. Will producers using sugar (e.g. for the production of confectionery, juices, syrups, etc.) or oil (e.g. for mayonnaise or prepared food), reduce the prices of these products after the VAT rate for sugar and oil is lowered?

Finally, there is the issue of a clear identification of products to be taxed at a reduced rate (Kesner-Škreb, 1999). What exactly is considered to be the infant food? How are, for example, biscuits or fruit juices intended for young children differentiated from other such products?

Introducing reduced VAT rates for certain products is bad, because it complicates and increases the costs of the tax system, i.e. the tax collection and control, impairing the tax system efficiency.

\section{VAT REGISTRATION THRESHOLD}

Despite the importance of the registration threshold for value added taxation, there are relatively few studies in both the economic theory and practice, dealing with this issue in greater detail. On of them tries to determine an optimal threshold for VAT registration (Keen and Mintz, 2004.), analysing the impact of the threshold level on tax revenues and taxation costs. A threshold that is too high may, due to the non-inclusion of a particular number of taxpayers in the VAT system, result in tax revenue losses. On the other hand, a threshold that is too low is burdensome for both tax administration and taxpayers, and it increases taxation costs. The problem is made even worse, given the distortion of market competition, arising from different tax treatment of VAT-registered and non-VATregistered taxpayers. In most developed countries, tax administrations increase the VAT registration threshold in order to reduce the burden of too many taxpayers with low turnovers.

While the Council Directive 2006/II2/EC provides for a minimum threshold (EUR 5,O00), during the EU accession negotiations Croatia was given the option to increase the VAT registration threshold (which has not changed since 1999) from HRK 85,000 to a maximum of HRK 230,00o. The latter amount has been incorporated in the new VAT Act and becomes applicable as of I January 2013. This change should facilitate the operation of entrepreneurs with lower turnovers and thus reduce their business costs, as they will be no more required to determine their tax liabilities or submit the legally prescribed tax forms. Taxpayers who wish to stay in the VAT system can do so, but are then obliged to remain registered for another 5 calendar years.

The above-described amendments also include increasing the threshold for quarterly vs. monthly reporting from HRK 300,000 to HRK 800,000. Under such regime, a "small entrepreneur" will have to submit only four, instead of 12 forms in a year, which will reduce costs for both the taxpayer and the tax administration.

\section{LIMITATION OF THE RIGHT TO INPUT TAX DEDUGTION}

\section{ABOLITION OF INPUT TAX DEDUGTION FOR MEANS OF TRANSPORTATION}

The current $70 \%$ input tax deduction for the procurement, lease and maintenance of personal motor vehicles and other means of transportation has opened up possibilities for tax evasion and under-reporting of taxable revenues. So far, only the taxpayers whose procurements of personal vehicles and other means of transportation exceeded HRK 400,00o have been excluded from deducting input tax. The Tax Administration has become aware of the drawbacks of such provisions and a lack of transparency in their application. Therefore, according to the amendments to the Act, applicable as of I March 2OI2, the input VAT deduction for the procurement and lease of vessels for entertainment purposes, planes, personal motor vehicles and other personal means of transportation, including the procurement of all goods and services pertaining to them, has been fully abolished.

The said provisions do not apply to vessels and planes intended for the transportation of passengers and goods, for rental or resale, or to personal motor vehicles and other personal means of transportation used for driver training, vehicle testing, repair and maintenance services, the transportation of passengers and goods, transportation of deceased and for rental or resale.

This change is bound to result in a slump in car sales, stimulated by a higher general VAT rate. The abolition of input tax deduction for the means of transportation maintenance (repairs, spare parts, road tolls and fuel) will increase the costs for entrepreneurs, but they will still be allowed to declare the total amounts of invoices as costs (including VAT). 


\section{ABOLITION OF INPUT TAX DEDUGTION FOR ENTERTAINMENT PURPOSES}

Pending the amendments to the Act, a 30\% input tax deduction was allowed for business entertainment expenses. Under the new regulations, the right to input tax deduction for the procurement of goods and services for entertainment purposes does not exist any more. The entertainment expenses include the cost of entertaining business partners and presenting them with gifts, their vacation, sport and leisure costs, and the leasing costs of motor vehicles, vessels, planes, vacation houses, etc.

If such goods are subsequently delivered, and if no input tax was deducted at the time of procurement, they are exempt from VAT.

\section{FISGAL EFFEGTS OF INPUT TAX DEDUGTION}

By abolishing the right to input tax deduction, the Tax Administration intends to prevent tax evasion for goods used for private purposes, but procured through a legal entity, thus preventing taxpayers from paying their private bills through the company.

According to the Ministry of Finance's estimate, the annual financial effect of the abolition of input tax deduction for business entertainment and motor vehicles expenses for the Io-month period this year will amount to HRK 550m.

\section{GHANGES IN PENAL PROVISIONS}

The prescribed amounts of fines for taxpayers' offences range between HRK I,OOO and HRK 500,000. Under the amended Act, the fines for persons responsible for carrying out certain operations on behalf of taxpayers are also increased, from HRK IO,OOO to HRK 40,00O and from HRK 2O,000 to HRK 50,000.

\section{ADDITIONAL EFFEGTS OF GHANGES IN THE VAT SYSTEM}

Each tax reform involves practical difficulties that are hard to measure or express in terms of money. As of I March 20I2, all entrepreneurs and traders will have to declare their turnovers in their books and invoices according to the new tax rates. All cash registers and price lists will have to be adequately adjusted. Adjustments will also be necessary for accounting software, including the creation of new forms. Some traders will have to change the prices of thousands of commodities. All this represents additional taxation costs caused by the changes in the VAT system. The change in rates and the extension of the scope of application of the reduced rates will require more work from both taxpayers and the Tax Administration.

\section{GONGLUSION}

Today, Croatia is not the only country encumbered with economic, fiscal, debt, corruption and social welfare problems. How can an adequate solution be found and what instruments should be applied in order to overcome these problems? As concerns fiscal stability and resolving the deficit and public debt issues, it is necessary to take measures on both the revenue and expenditure sides of the budget. The revenue side is largely contingent on tax revenues. Each change in the tax system affects the public sector, the economy and citizens. Therefore, it is necessary to analyse the economic effects and monitor their materialisation in the future. However detailed and thorough these analyses may be, some parameters are difficult to estimate in an unstable economic situation.

The changes in VAT rates are expected to increase revenues, assuming no consumption and economic activity reductions. The higher rate will result in higher goods and services prices, which may lower the living standards of citizens. On the other hand, the application of lower rates to some basic foodstuffs should alleviate the negative effects on the living standards of citizens, provided that traders and producers really reduce the prices of these products. However, instead of applying lower rates, it would be better to take measures on the expenditure side of the budget, by providing social transfers to the most vulnerable groups of population and increasing the basic personal allowance for personal income taxation.

Raising the VAT registration threshold and the amount for quarterly VAT reporting will drive down taxation costs for both taxpayers and the Tax Administration. As the new regime becomes effective on I January 2013, there is enough time for analysing and estimating its effects on budget revenues.

Budget revenue losses can be caused by legal and illegal reasons. The former relate to legal provisions allowing tax avoidance or evasion, whereas the latter arise from the violation of regulations, such as the failure to pay tax or carrying on business in the grey economy. The abolition of input tax deductions for the procurement, lease and maintenance of means of transportation and for business entertainment will ensure more transparent implementation of the VAT Act and discourage tax evasion. However, a much larger challenge is posed by tax arrears or tax debt, now reaching a record high of HRK 42bn, (of which the government expects to collect HRK 25.8bn).

The next year's deficit is planned to reach HRK 9.9bn, which makes one fourth of uncollected tax revenues. Is the government capable of collecting at least a portion of this debt accumulated for so many years? 
Efficient tax collection, a stable and transparent tax system, an equitable distribution of tax burden in an environment of stable economic and employment growth are the key prerequisites for achieving fiscal consolidation and correcting fiscal imbalance.

\section{LITERATURE}

Blažić, H., 2004. "Troškovi oporezivanja u Hrvatskoj: troškovi poreznih obveznika i troškovi poreznih vlasti”. Financijska teorija i praksa, 28 (3), 27I-29I.

DZS, 20II. Priopćenje: Indeks potrošačkih cijena u prosincu 2OII, No. I3.I.I/I2. Zagreb: Državni zavod za statistiku.

European Commission, 20II. A budget for Europe 2020. COM(2OII) 500 final. Brussles, 29.6. 20II. Available at: [http://ec.europa.eu/budget/library/biblio/documents/fin_fwki42O/MFF_COM-2OII-50O_Part_I_en.pdf].

Hrvatski sabor, 2012. Državni proračun Republike Hrvatske za 20I2. godinu. Available at: [http://www.sabor. hr/Default.aspx?art=46372].

Keen, M. i Mintz, J., 2004. "The optimal treshold for a value-added tax". Journal of Public Economics, 88, 559-576

Kesner-Škreb, M., 1999. “Ten Reasons in Favour of a Uniform Rate of a Value Added Tax”. Newsletter, No. 2. Available at: [http://www.ijf.hr/eng/newsletter/2.pdf].
Kuliš, D., 2009. Analiza učinaka promjene visine praga za ulazak u sustav PDV-a. The project carried out by the Institute of Public Finance, sponsored by the Ministry of Finance of the RC.

Ministry of Finance, 2009. Godišnje izvješće Ministarstua financija za 2009. godinu. Zagreb: Ministarstvo financija.

Ministry of Finance, 20II. Mjesečni statistički prikaz Ministarstva financija. Available at: [http://www.mfin.hr/ adminmax/docs/193\%20-\%2OListopad.pdf].

Ministry of Finance, 20I2. Prijedlog mjera i smjernice za izradu proračuna za 20I2. godinu. Dostupno na: [http:// www.vlada.hr/hr/naslovnica/sjednice_i_odluke_vlade_rh/2OI2/5_sjednica_vlade_republike_hrvatske/5_ oI/(view_online)/I\#document-preview].

Ott, K., 2012. "O poreznim promjenama i novom proračunu”. Banka, I8 (3), 6-7.

Ott, K. (i sur.), 1996. "Analiza fiskalnog sustava RH pri uvođenju poreza na dodanu vrijednost". Financijska teorija i praksa, 20 (2), 129-258.

Urban, I., 20II. "Distribution of tax burden in Croatia". Newsletter, No. 58. Available at: [http://www.ijf.hr/ eng/newsletter/58.pdf].

Vresnik, V., 2012. “Još dva tjedna do poreznog udara. Je li vrijeme za veliki spasilački šoping?” Jutarnji list, I2. veljače 2012. 